\title{
‘Florida-07', a Medium Maturity, Large Seeded, High Oleic Peanut Variety with Resistance to Tomato Spotted Wilt ${ }^{1}$
}

\author{
B.L. Tillman and D.W. Gorbet ${ }^{2}$
}

'Florida- 07 ' peanut variety was developed by the University of Florida, Institute of Food and Agricultural Sciences, North Florida Research and Education Center near Marianna, Florida. The variety was released in 2006 because of its outstanding pod-yield potential, competitive grades, high oleic oil chemistry and resistance to tomato spotted wilt virus (TSWV).

Over several years of testing in Florida, the pod yield of 'Florida-07' has been excellent, and the grade (TSMK-Total Sound Mature Kernels) has been competitive with other varieties (Table 1). In addition, 'Florida-07' has very good resistance to tomato spotted wilt virus with a rating of 2.1 , compared to a rating of 4.2 for 'Georgia Green' (using a rating scale of 1 - 10 with $1=$ no disease). 'Florida-07' has also performed well in Alabama and Georgia.

In the 2006 Alabama peanut variety tests at Headland, pod yield of 'Florida-07' ranked first in both irrigated and non-irrigated tests: http://www.aaes.auburn.edu/comm/ pubs/agronomy/ay282.pdf. Similarly, in 2007 pod yield of 'Florida-07' ranked second in the irrigated test and first in the non-irrigated test: http://www.aaes.auburn.edu/comm/ pubs/agronomy/ay291.pdf. In both tests, the TSMK of 'Florida-07' was competitive with other varieties although it did not have the highest grade. In the Georgia peanut variety tests, pod yield of 'Florida-07' ranked no less than fifth in three irrigated tests and two non-irrigated tests: http://www.swvt.uga.edu/2006/pct06/RR709-contents.pdf. Similarly, in 2007 pod yield of 'Florida-07' was ranked not less than fourth in five out of six tests: http://www.swvt. uga.edu/2007/pct07/RR714-Peanut.pdf. In all tests, the TSMK of 'Florida-07' was competitive with other varieties, but was not among the highest group.

The seed size of 'Florida-07' is larger than that of 'Georgia Green' and 'C-99R'. In three years of testing at two locations in Florida, 'Florida-07' had an average of 591 sound mature kernels (SMK, those riding a 16/64 inch screen) per pound. These results compared to 655 per pound for 'C-99R' and 858 per pound for 'Georgia Green'. The results indicate more pounds of seed of 'Florida-07' will be required to plant the same seeding density as 'Georgia Green' or 'C-99R'. However, the SMK group contains jumbo runner seed, medium seed and number one seed. It is not likely that jumbo runners will be used for seed, which should increase the seed count per pound and reduce the pounds of seed per acre required for planting.

'Florida-07' has a typical runner growth habit with a semi-prominent central stem and dark green foliage. Under irrigated conditions in Florida, 'Florida-07' reaches optimum maturity about 140 days after planting. Because the

1. This document is SS AGR 313, one of a series of the Agronomy Department, Florida Cooperative Extension Service, Institute of Food and Agricultural Sciences, University of Florida. Original publication date November 2008. Reviewed May 2012. Visit the EDIS website at http://edis.ifas.ufl.edu.

2. B.L. Tillman, assistant professor, and D.W. Gorbet, professor, Department of Agronomy, North Florida Research and Education Center, Quincy, FL, Institute of Food and Agricultural Sciences, University of Florida. 
variety has large seed, gypsum is recommended, especially when producing seed of 'Florida-07'.

Production of seed of 'Florida-07' is governed by PVP (Plant Variety Protection), such that seed of this variety can be produced and sold only as a class of certified seed and only by companies licensed by the Florida Foundation Seed Producers, Inc. In addition to PVP, 'Florida-07' is protected by three U.S. utility patents because it is high oleic. These patents do not have a farmer exemption for saving seed, as provided under PVP. As a result, farmers are prohibited from saving seed from their own farm to plant the following season. 


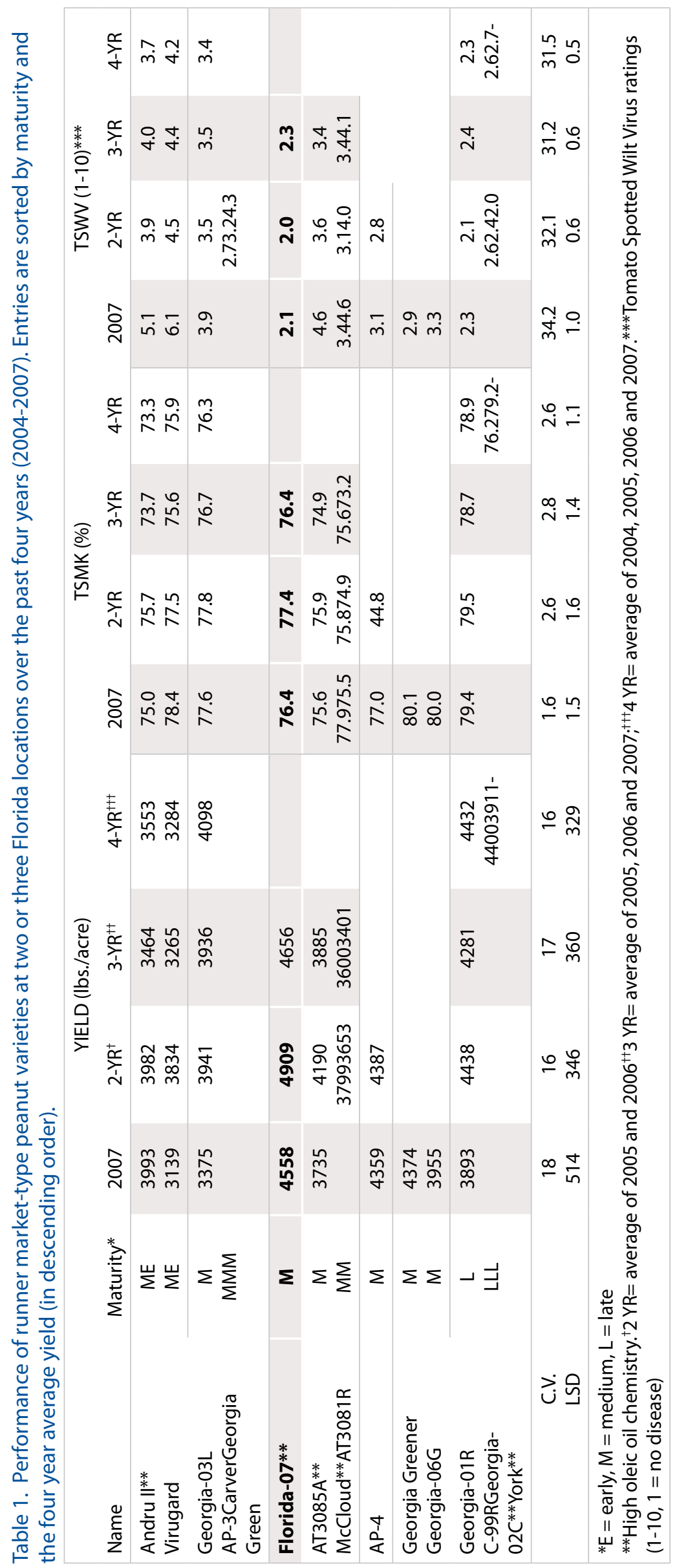

